\title{
Application composite of iron sand extract and activated charcoal of cashew nuts as powder ink (toner)
}

\author{
Erniwati $^{1}$, Suci Rahmadhani Ahmanas ${ }^{2}$, Suritno Fayanto ${ }^{3}$, Nanang adrianto ${ }^{4}$, Ahmad $^{5}$, \\ Muhammad Abdullah Azam Undu ${ }^{6}$, Sulwan ${ }^{7}$, Kadek Yudha Setiawan ${ }^{8}$, Muhammad Anas ${ }^{9}$, \\ Hunaidah $^{10}$ \\ \{erniwatisirih66@gmail.com ${ }^{1}$,rahmadhanisuci11@gmail.com² ${ }^{2}$, suritnofayanto@gmail.com ${ }^{3\}}$ \\ Physics Education, Universitas Halu Oleo, Jl. H.E.A. Mokodompit, Kendari 93231 Indonesia ${ }^{1345678910}$, \\ Physics Education, Universitas Ahmad Dahlan, Jl. Pramuka No.42 Yogyakarta, 55161 Indonesia $^{2}$

\begin{abstract}
This study aims to utilize the extracts of iron sand and activated charcoal of cashew nut shells as the preparation of powder ink (Toner). Samples through several stages, carbonate stage of cashew nut samples at $500^{\circ} \mathrm{C}$ for 9 hours using pyrolysis reactor, extraction phase of iron sand sample, grinding stage and sieving 200 mesh, activation charcoal of cashew nut shells using furnace electrical a temperature of 700C for 30 minutes, the next stage of mixing the samples for 5 hours with activated charcoal mass fraction of $40 \%, 60 \%, 80 \%$, followed by mixed with polyacrylic acid 10 gram, then dried using a furnace at $150^{\circ} \mathrm{C}$ for 30 minutes, crushed and sieved to $200 \mathrm{mesh}$. The results of yield of the received toner grain size of $2.90 \mu \mathrm{m}, 3.21 \mu \mathrm{m}$, and $4.91 \mu \mathrm{m}$. Analysis show that the composite of iron sand and active leather levels qualified to be made as a toner.
\end{abstract}

Keywords: powder ink (toner), iron sand extract, actived cahrcoal of cashew nuts.

\section{Introduction}

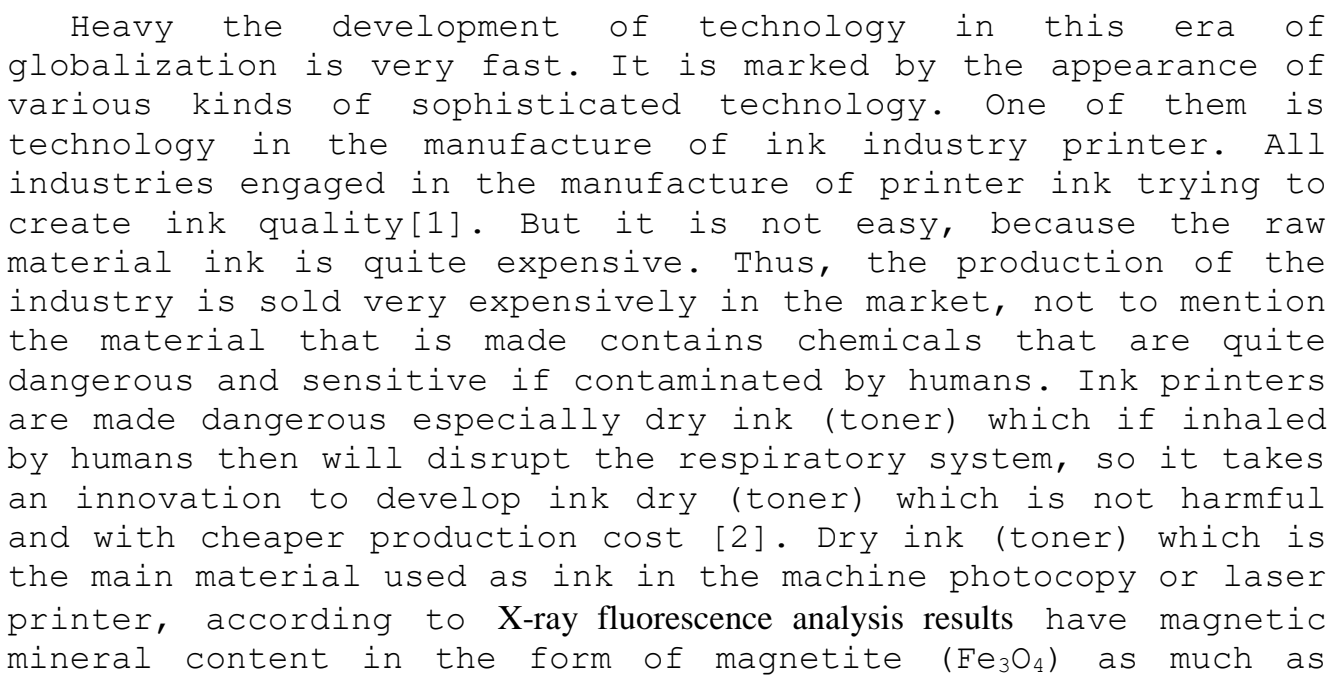

ICCSET 2018, October 25-26, Kudus, Indonesia

Copyright (C) 2018 EAI

DOI 10.4108/eai.24-10-2018.2280535 
95,01\%. This magnetic mineral is the dominant mineral in toner with composition $>90 \%$ [3].

Dry ink (toner) also contains a carbon powder, but the carbon usually mixed with some addictive ingredients such as styrene acrylate copolymer and hydrocarbon resins or other materials there by improving print quality and adhesion on paper and additives used for electrophotography (EP) printing [4]. In the past few decades, EP has become a legitimate alternative to analog print production technology. The main material of the toner containing magnetic material $\left(\mathrm{Fe}_{3} \mathrm{O}_{4}\right)$ is present in iron sand, where as carbon powder can be obtained from carbonation and activation of natural materials such as cashew nut shell wastes, it is more likely to produce dried ink (toner) qualified, effective, efficient and most importantly is safe in its use. Purpose used such materials other than non-toxic materials are also readily available and contain no chemicals dangerous. The ease of obtaining iron sand and cashew nut shells is supported from the abundance of sand iron and cashew nut found in southeast sulawesi.

Iron sand is an iron ore that is used as raw material for steel industry, as well used in cement industry, titanium industry, an oxide with magnetite content $\left(\mathrm{Fe}_{3} \mathrm{O}_{4}\right)$. It is very potential to be developed as a basic material for making a toner. One of the areas that contain lots of iron sand is Laompo Village Batauga district Buton. From the results of research conducted by iron sand found in Laompo district Kambowa regency of north Buton has elemental content such as Silicon dioxide $\left(\mathrm{SiO}_{2}\right.$ 33.756\%, Magnesium oxide $(\mathrm{MgO}) 6.617 \%$, Trioxide ferry $\left(\mathrm{Fe}_{2} \mathrm{O}_{3}\right)$ 12.613\%, Iron $(\mathrm{Fe}) 8.829 \%$, Calcium oxide $(\mathrm{CaO}) 4,058 \%$, and Aluminum oxide $\left(\mathrm{Al}_{2} \mathrm{O}_{3}\right)$ 8,096\% [5].

The potential of iron sand is related to its properties and characteristic of magnetic mineral contained in powder ink (toner). Cashew plants produce fruits and seeds, where cashew seeds have a skin is one of agricultural waste that is very potent and not utilized by the community[6]. The five-yearly data of cashew plantation sub-sector from 2008-2012 shows the average production of cashew nuts is 130.295.6 tons [7]. Approximately $49 \%$ of Indonesian cashew production is exported, both in the form of logs $(36 \%)$ and in the form of cashews (13\%), while the remaining $51 \%$ is to meet domestic needs [8]. Cashew nuts consist of $70 \%$ seed coat and $30 \%$ seed meat [9]. Cashew seed skin (KBM) is waste produced in the postharvest industry by typing cashew nuts. Cashew seed skin has not been utilized to its full potential, most of it is still a waste. The average 2008-2012 cashew nut production data shows the average amount of KBM waste that can be obtained per year is around 58.372.43 tons. This solid waste contains $32-37 \%$ oil known as lake oil or CNSL contains natural phenol compounds composed of sonardic acid, cardamom, 2- methyl Cardiol and cardanol and according to the results of energy dispersive $\mathrm{x}$-ray analysis of cashew nut shells have a carbon content high ie $96.65 \%$ [10]. The structure of the cashew nut shell consists of the outer layer and the middle layer of the structure such as a honeycomb containing CNSL, and a hard inner layer so produce good activated carbon [11].

Some research on toner cartridges has been done such as the manufacture of toner material light ash and with the addition of iron sand or produced from activated carbon magnetic waste tissue. Therefore, from the results of the above thought writers interested in conducting research with a title of utilization of iron sand composite and activated charcoal of cashew nut shells as a base material of toner manufacture. 


\section{Materials and methods}

\subsection{Raw materials}

The raw materials used in this research are as follows: iron sand, cashew nut, polystyrene acid, mortar, sifter, plastic sample, sample paper, electrical furnace, analytical balance, porcelain grille, glass chemicals, hot plane, alcohol, aquades, and molds.

\subsection{Active charcoal preparation}

This stage of activated charcoal making begins with the preparation of a sample of cashew nut waste, waste carbonation cashew nut shells with temperature $500{ }^{\circ} \mathrm{C}$ for 9 hours, griding charcoal of cashew nut shell up into a fine powder, sieving a scoured sample size of 200 mesh up to stage activation of sample with temperature of $700{ }^{\circ} \mathrm{C}$ for 30 minutes.

\subsection{Iron sand extraction}

Iron sand extraction is done through several stages of iron sand sample preparation, separation of material magnetic with other materials using the magnet as much as 5 times repetition by way of a magnet near the iron sand to produce magnetic material and followed by scouring process and sieving with 200 mesh size.

\subsection{Preparation toner}

Composite making of the active iron-charcoal extract of cashew nut waste is done by process mixing between iron sand and activated charcoal cashew nut shell waste with $40 \%$ activated carbon mass fraction, $60 \%, 80 \%$ use homogeneous devices. The composite result of active iron-charcoal extract of cashew nut waste was mixed with the glue polyacrylic acid 10 gr that has been melted, then dried using a furnace at temperature $150^{\circ} \mathrm{C}$ for 30 minutes in the mold, the result is then crushed again using mortar until it becomes powder smooth and sieve using of 200 mesh. analysis technique using scanning electron microscope for characterization results to determine the size distribution toner [12]. Next, analysis and characterization of toner by using Electron Scanning microscope and Image-J know the structure and size of the surface of activated carbon.

\section{$3 \quad$ Results and discussion}

\subsection{Characterization toner using Scanning Electron Microscope (SEM)}

Toners that have been produced with variations of active charcoal mask $40 \%, 60 \%$ and $80 \%$ analyzed by using scanning electron microscope to determine the size of the toner and grain the structure of the toner. The results of the scanning electron microscope (SEM) analysis with using magnification of 1000x. Figure 1, Figure 2 and Figure 3 shows the SEM micrograph of toner particles. It can be seen that all toner particles are approaching round and some are 
irregular. this certainly affects the size of the toner particle magnetite and the quality of the size of the grain of toner influenced by the active charcoal mass of $40 \%, 60 \%, 80 \%$ of the charcoal from the iron sand. It is visible of the yield of the received toner grain size of 2.90 $\mu \mathrm{m}, 3.21 \mu \mathrm{m}$, and $4.91 \mu \mathrm{m}$.

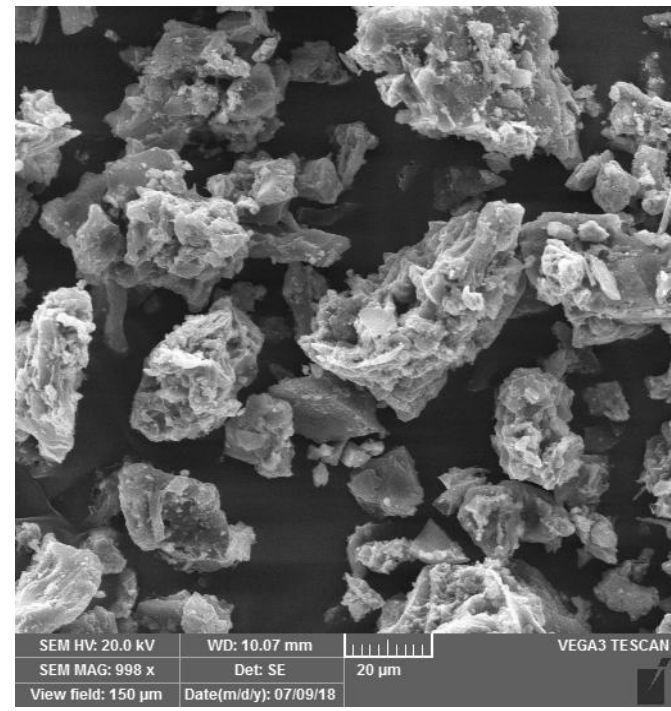

Fig. 1. activated charcoal mass fraction of $40 \%+$ $60 \%$ iron sand.

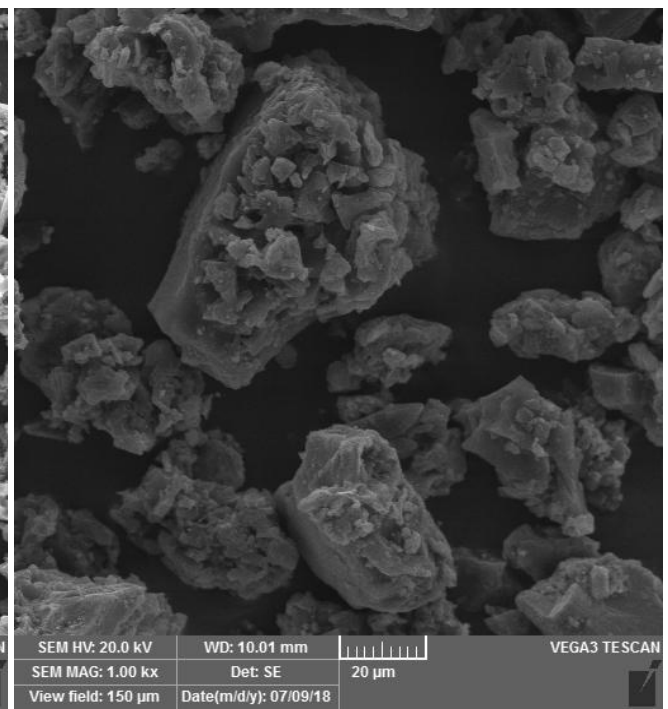

Fig. 2. activated charcoal mass fraction $60 \%+$ $40 \%$ iron sand.

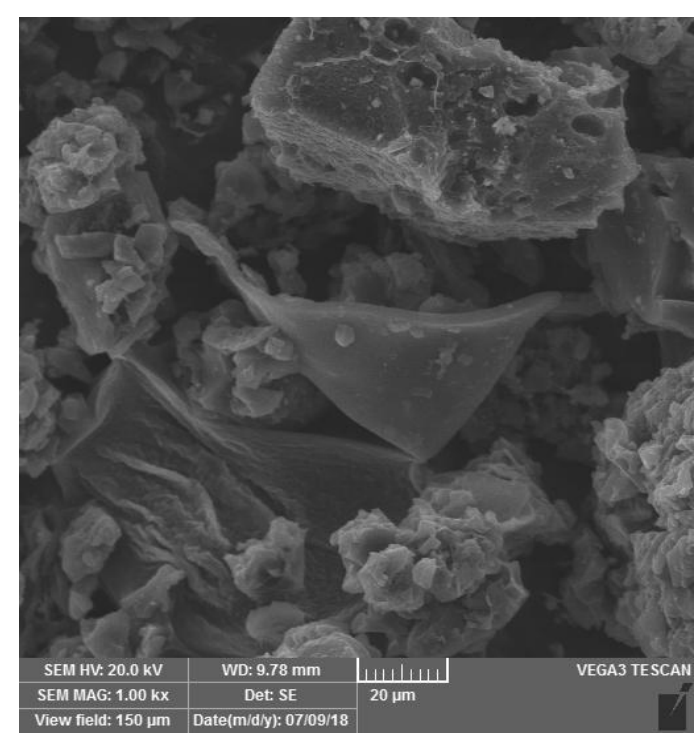

Fig. 3. activated charcoal mass fraction $80 \%+20 \%$ iron sand. 
The resulting toner can also be said in good toner quality, as it falls into the category of good quality toner. It is also supported by research Hays that in general good quality toner has a particle size below $10 \mu \mathrm{m}$ [13]. The particle size and particle size distribution of the toner are shown in Figure 4. The particle size of the distribution show that all toner size distributions are in the right range (2-4nm) [14]. Smaller magnetite nanoparticles produce toner with a smaller particle size and particle size distribution, which will produce quality toner.

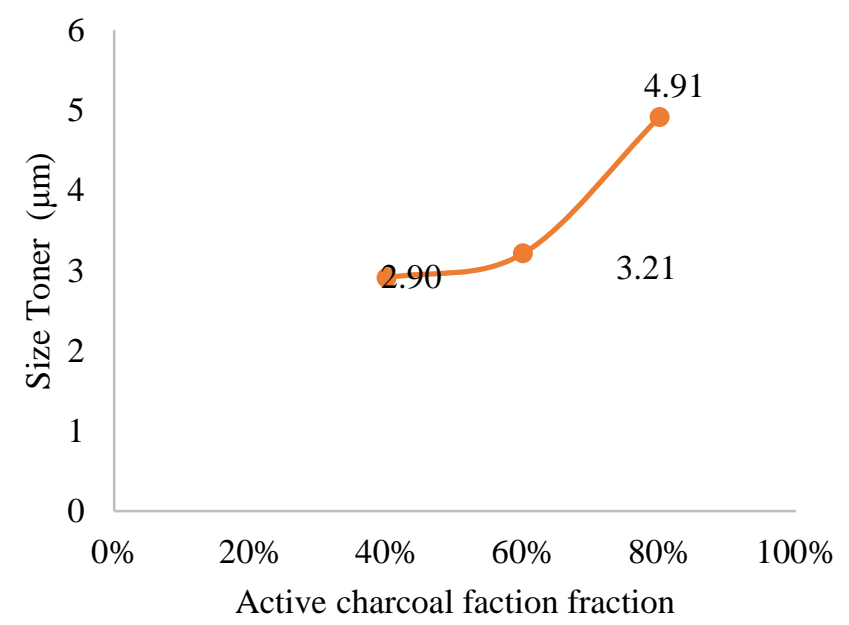

Fig. 4. Graph of the effect of activated charcoal massa fraction on the quality of the toner grain size.

Raising this graph shows that the yield of toner obtained has a level of efficiency which is high from raw materials to making way makes it superior to toner market, so the composite iron sand extract and activated charcoal of cashew nut shells have the potential to be used as an ingredient in the manufacture of toner, plus materials that are abundant and inexpensive so as not difficult to obtain. From the data above data so that obtained a thought that composite extracts of iron sand and activated charcoal of cashew nut shells can be utilized as the basic ingredients of manufacture toner.

\section{Conclusion}

Have been successfully analyzed a toner made from composite extracts of iron sand and activated charcoal waste of cashew nuts. The results of SEM analysis showed that all iron sand mass fractions and activated charcoal of cashew nut shells were included in the toner category with diameters of $2.90 \mu \mathrm{m}, 3.21 \mu \mathrm{m}$, and $4.91 \mu \mathrm{m}$.

\section{Acknowledgements}

The author's gratitude to the Ministry of Research, Technology and Higher Education who has funded the Research. Likewise, the author thanks to the lecturer and mentors Dr. Muh. Anas, M.Si., Dra. Hj. Erniwati, M.Si and Suritno Fayanto, S.Pd for the guidance provided. 


\section{References}

[1] T. Sonia, H. Timer, F. William, N. Chris, "Design and characterisation of food grade powders and inks for microstructure control using 3D printing," J. Food Eng., vol. 30, pp. 1-8, 2017.

[2] P. Sisri, W, N. Arif, B. Dwi, "Karakterisasi struktur kristal dan sifat magnetik maghemit $(\gamma-$ $\mathrm{Fe} 2 \mathrm{O} 3)$ yang dioksidasi dari magnetit $(\mathrm{Fe} 3 \mathrm{O} 4)$ dari pasir besi batang sukam kabupaten sijunjung sumatera barat dengan variasi waktu oksidasi," J. Fis. Unand, vol. 5, pp. 1-4, 2016.

[3] K. Rastko, M. Uroš, N. Bojan, B. Dragoljub, N. Nemanja, "The analysis of ink jet printed ecofont efficiency,” J. Graph. Eng. Des., vol. 7, pp. 13-17, 2016.

[4] E. Maryam, A. Ebrahim, G. Mona, "Effect of micro and nanomagnetite on printing toner properties," Hindawi Sci. world J., vol. 10, pp. 1-7, 2013.

[5] Haslinda, "Pengaruh temperatur pemanasan terhadap kandungan unsur dan nilai suseptibilitas magnetik pasir besi di desa laompo kecamatan batauga kabupaten buton selatan," Univ. Halu Oleo Kendari, pp. 1-35, 2015.

[6] A. Muhammad, "Arang aktif kulit jambu mete dengan menggunakan aktivator $\mathrm{HCl}, \mathrm{H} 2 \mathrm{SO} 4$, dan $\mathrm{NaOH}$,” Univ. Negeri Gorontalo, pp. 1-6, 2015.

[7] Ditjenbun, "Statistik perkebunan jambu mete indonesia 2008-2012. Direktorat jenderal perkebunan," pp. 5-30, 2013.

[8] A. W. Indrawanto, C. Wulandari, "Analisis faktor-faktor yang mempengaruhi keberhasilan usahatani jambu mete di Sulawesi Tenggara. Jurnal Penelitian Tanaman Industri,” vol. 9, pp. 141148, 2003.

[9] N. Simpen, I, "Isolasi cashew nut shell liquid dari kulit biji jambu mete (Anacardium occidentale L.) dan kajian beberapa sifat fisiko-kimianya," J. Kim., vol. 2, pp. 71-76, 2008.

[10] K. Himejima, I, "Antibacterial agent from the cashew anacardium occidentale 1 (anacardiaceae) nut shell oil," J. Agric. Food Chem., vol. IX, pp. 418-421, 1991.

[11] J. Kumar, P, P. Paramashivappa, R. Vithayatil, P, "Process for Isolation of cardanol from technical cashew (Anacardium occidentale L.) Nut shell liquid," J. Agric. Food Chem., vol. 50, pp. 4705-4708, 2002.

[12] F. Sukma, "Sintesis dan karakterisasi tinta kering (toner) berbasis pasir besi dengan metode polimerisasi emulsi," Univ. Negeri Malang, pp. 1-6, 2017.

[13] A. Hays, D, "The evolution of color xerographic development systems," J. Imaging Technol, vol. 6, pp. 252-258, 1991.

[14] A. Maryam, "Production of carbon black acrylic composite as an electrophotographic toner using emulsion aggregation method: investigation the effect of agitation rate," J. Compos. B, vol. 64, pp. 78-83, 2014. 